Palchenkova V. M.,

Doctor of Sciences (Law), Professor, Head of the Department of Theory and History of State and Law, Law Institute named after Volodymyr Stashis of the Classic Private University, Zaporizhzhia, Ukraine

\title{
THE FUNCTIONING OF THE SOCIAL PATRONATE: THEORETIC AND LEGAL ASPECT
}

Social patronage (derived from the Latin "Patronus", the French "Patronage" patron, patron, supervision, patronage, guardianship) and literally implies any patronage stronger in the physical, moral or legal understanding of the individual in relation to the weak. Patronage can mean providing a material, moral, in a broad sense, social assistance and support.

The report considers various historical forms and forms of patronage. Depending on the subjects of the exercise of patronage, he could be state, public or private, secular or ecclesiastical, depending on the objects - could be carried out over slaves, freedmen or free people, to touch certain categories of the population - children, women, former prostitutes, and former prisoners (Special prison patronage).

Presented is the modern definition of patronage, its subjects and activities.

The law defines the list of social patronage services, to which, in addition to the social services defined by the Law of Ukraine "On Social Services", medical, legal, educational, rehabilitation and other services are included. Specific measures of social patronage have been defined, namely: the restoration of documents and the registration of the place of residence, the provision or preservation of housing, medical care, services, the examination of exempted persons, the provision of additional job security. It is envisaged that the subjects of the social patronage, in the case of the release of liberated persons, are obliged immediately to start implementing measures of social patronage against such persons.

Key words: social patronage, social services, forms, types, measures.

Target setting. Progressive development of the society and its promotion to a certain ideal are impossible without proper protection of the members' of such society rights and freedoms at all levels and in all spheres of life. One of the components of forming of lawgoverned state is the renewal and improvement of public control over activities of state authorities, in particular of the Criminal and Executive System of Ukraine, and the whole system of execution of punishments. In this regard, today it is necessary to pay attention to social patronage as a special form of public control.

Social patronage is carried out in relation to persons serving a sentence in the form of restraint of liberty or imprisonment for a cer- 
tain period of time, and for released persons (citizens of Ukraine, foreigners and stateless persons who legally live at the territory of Ukraine) to those, who have turned to the subjects of social patronage during six months after the release from penitentiary institutions.

The purpose of the article. Society, demanding from the state institutions unconditional execution of laws and observance of human rights, should not remain indifferent to the problems of law enforcement bodies, including the Penitentiary System in which the rights of persons being investigated or convicted are violated in most cases deliberately, not for the purpose of evil intent, but because of lack of necessary, in particular material, conditions.

It is the solidarity, partnership and corrective nature of the control over the activities of the Penitentiary System will enable its turning into an institution of socialization of the offender's personality, which meets the requirements of civilized society.

The statement of basic materials. All this causes the development of theoretical, organizational and legal foundations, as well as administrative mechanisms of the system of control the execution of punishments by civil society institutions improving. Public control as an institution and social practice, like any other phenomenon of social life, undergoes historical transformation (changes). Reforms in the system of execution of punishment should always be based on historical experience. Therefore, the purpose of this article is to reveal the content of social patronage, its volume, types and forms in the historical dimension, factors influencing the effectiveness of patronage in the conditions of functioning of modern society.

Social patronage - (derived from the Latin «patronus», the French «patronage» - the master, protector, supervision, patronage, care and «socialis» - a social or «socius» - a friend), and literally provides any person's stronger in physical, moral or legal sense intercession in relation to the weaker one. Protection can mean giving material, moral, in broad sense social assistance and support. Various historical forms and forms of social patronage are known. Depending on the subjects of implementation, it could be state, public or private, secular or church, depending on the objects - could be carried out over slaves, freedmen or free people, to touch upon certain categories of the population - children, women, former prostitutes, and also 
former prisoners (special jail patronage). In modern sense it is the type of social service of people at risk, including convicts, which provides for constant social supervision.

Social patronage is carried out, as a rule, in an individual form. It provides for regular visits by social workers to the place of ward's staying, providing him with necessary social, medical, sociopsychological, socio-pedagogical, socio-economic and socio-legal assistance.

The basic principles of the implementation of social patronage are: systematic, comprehensive, effective use of potential and positive reserves of wards' social and family environment, strengthening their own potential opportunities with the aim of solving everyday and vital problems individually.

It should be emphasized that the supervised person receives specific assistance and support from the service, which is designed to mobilize and enhance its adaptive capacity in society.

The first associations of patronage type appeared in the United States: in 1776 in Philadelphia appeared the Society for the Assistance to Dismissed Prisoners, founded by Richard Whistler, in 1824 a similar organization began to work in Boston. In Europe, the first patronage association was founded in 1797 in Denmark, but it was widespread in the last quarter of the nineteenth century. The first special society of curatorship on persons released from places of imprisonment in the Russian Empire is considered to be established in 1878 by the patronage association in Kyshynev. The establishment of patronage societies in the Russian Empire was rather slow, for example, at the beginning of the twentieth century in Ukrainian provinces Societies of the patronage over the liberated ones from places of detention worked only in Kyiv (1902), Odessa (1887) Kharkiv (1905) and Vinnitsa (1912) [1, p. 48].

At legislative level, for the first time in the Russian Empire, the activities of the societies that provided social assistance to the convicts were regulated by the Normal charter of the patronage over the dismissals approved on September 10, 1908.

Actual scientific researches and issues analysis. One of the first who described the forms of practical implementation of the patronage were German specialists in the field of Police (Administrative) Law 
R. Mol, L. Shtein, H. Meiier, who interpreted it exclusively as an institution for the stay of persons released from places of imprisonment, and juvenile offenders released from shelters.

Active scientific and theoretical study of the issue of prison patronage, in particular in the Russian Empire, began to be carried out in the 90's of the nineteenth century in connection with the abolition of exile to Siberia, a sharp increase in the number of convicts sentenced to imprisonment and the adoption in June 22, 1909, the law "On conditional release". The idea of the prison patronage was grounded in scientific and practical developments of such theorists and practitioners of penitentiary work as E. Barantsevych, E. M. Hohel, S. K. Hurliand, I. Ya. Luchynskyi, M. F. Liublinskyi, P. I. Malinin, F. M. Poznyshev, S. V. Serhiievskyi, M. D. Tahantsev, M. S. Feldshtein, H. S. Foinytskyi.

One of the first theoretical developments of the essence of patronage, not only in the Russian Empire, but in Europe in general, was I. Ya. Hurliand's paper "The idea of patronage as an idea of internal management". In it, the scientist found out the maintenance of the patronage in the broad and narrow sense, separating it from such types of society's control for the Penitentiary System, as charity and care. Under patronage, he understood the legal relationship, which subjects were determined by a legally strong and legally weak party (person), and the basis for their emergence recognized social insecurity as legal consequence of person's release from places of deprivation of liberty.

Penitentiary science of the nineteenth century has substantiated that vital interests of the state itself show the necessity of the establishment of an institution that would correct negative consequences of criminal punishment. The interests of the state and society are the same in this case. Each of them in its own way should contribute to the reduction and prevention of crime [2].

The principle bases on which the activity of patronage should be built, in a completed form, was formulated by S. V. Poznyshev. He referred to them the following: persons' who are highly moral and understand the importance of this case participation in the patronage; wide propaganda of patronage ideas in order to promote the emergence, consolidation and unification of local patron associations in- 
volved in the care of the dismissed, perform coordinating functions; improvement of the regulatory framework governing the activities of patronage societies and special institutions for work with visitors; publicity in the activity of patronage; the caution is that, firstly, care is provided not by everyone, but only by those who need it, and secondly, patronage should be based on voluntary basis and included into convicted prisoners' preparation for life in advance, in prison institution; creation of "labor repositories" for short-term stay in them, etc.

The term "patronage" over convicted and dismissed from places of deprivation of liberty was unknown to Soviet Labor and Correction Law and legislation. Although the authors of the Draft CorrectionalLabor Code of 1925 tried to preserve the system of patronage societies that arose already in the Russian Empire, but, in fact, the term "patronage" was not used in its own right; instead, the name was proposed "the organization of aid societies released from places of imprisonment", which would be financed, including through voluntary donations and contributions. With the including in the CLC of the Ukrainian SSR, these organizations received their legislative consolidation and development, and declared as one of the active forms of public participation in the fight against crime and its prevention. The control over the activities of the societies was carried out by party organizations and corresponding local councils of workers, peasants and Red Army deputies through their administrative departments. On this story, the organization of the Soviet patronage system can be completed, if not take into account the activities of the observation commissions, which according to the situation had to solve this problem, but in fact never did it. Meanwhile, some elements of social patronage were scattered across different institutions and branches of law. These include: a) facilitating the release of persons deprived of liberty in labor and domestic facilities; b) the activities of the observation commissions (until reaching the convicted majority - commissions on juvenile cases) in the executive committees of the local Soviets of People's Deputies; c) activities of juvenile offenders directed by public educators in accordance with the provisions on them; d) assigned by a court to a certain collective or individual, with their 
consent, the duties of supervising conditionally convicted and suspended-release relatives and conducting educational work with them.

In Ukraine, the first attempt at the state level to determine the conditions and procedure for providing social assistance to persons released from places of imprisonment, as well as the principles of participation in their social adaptation of executive authorities and local self-government bodies, enterprises, institutions, organizations and associations of citizens was carried out in 2003. The Law [3] provided official definition of the concept of social patronage as a set of measures of state support and assistance to the dismissed persons, which are carried out in order to facilitate these persons in employment, professional occupation, reorientation and retraining, creation of appropriate living conditions, prevent exposure to criminogenic factors. On August 30, 2004, by the decision of the Cabinet of Ministers of Ukraine, the program of social adaptation of persons released from places of imprisonment for 2004-2006 was approved, which provided for the implementation of specific measures on social adaptation of persons released from places of imprisonment and ensuring of their realization. It emphasizes that significant progress in counteracting such a dangerous social phenomenon as a recurrent crime can not be achieved without timely resolution of issues of social adaptation of previously convicted, providing them with the necessary assistance in solving social problems and employment. At the beginning of the twentieth century Ukrainian legislation provides that social adaptation of the laid-offs is carried out with the help of measures of social patronage, first of all by the state.

The emphasis is changed with the adoption on October 30, 2008 by the Cabinet of Ministers of Ukraine of the Concept of Social Adaptation of persons serving sentences in the form of deprivation of liberty for a certain term, the execution of which is scheduled for 2015. One of the expected results from the implementation of the concept is recognition of the creation of a mechanism for social rehabilitation of convicts and returning them to an independent, generally accepted social-normative life in society. On the way to realization of these tasks the priority has been recognized: development of volunteer programs; measures of post-penitentiary care and social patronage of persons released from places of deprivation or restraint of lib- 
erty. This idea was developed and enshrined in the Law of Ukraine of March 17, 2011 "On the social adaptation of persons serving or sentenced in the form of restraint of liberty or imprisonment for a specified period" [4].

Current legislation for persons who have served their sentences in places of deprivation of liberty, the legislation of Ukraine provided additional guarantees of the realization of their rights. These are the so-called "measures of social patronage". As noted by scholars, this Law defines social patronage as assistance to released individuals through the implementation of a set of legal, economic, organizational, psychological, social and other measures, in particular the provision of services aimed at their social adaptation [5]. According to the Law, the subjects of social patronage are central and local executive bodies and local self-government bodies, enterprises, institutions and organizations, associations of citizens, as well as individuals who carry out social patronage.

Modern social patronage, as in previous years, is carried out in respect of persons serving sentences in the form of restriction of liberty or imprisonment for a certain period, and on released persons (citizens of Ukraine, foreigners and stateless persons who legally reside in the territory Of Ukraine) who turned to the subjects of social patronage within six months after the release from penitentiary institutions. The main princes on which social patronage is based are recognized: legality; democracy; equality of citizens; targeting; Individual approach; accessibility and openness; voluntary choice or refusal of support; humanity; complexity; social justice; confidentiality.

The law defines a list of services for social patronage, which, in addition to social, defined by the Law of Ukraine "On Social Services", includes medical, legal, educational, rehabilitation and other services. Certain measures of social patronage are outlined, namely: restoration of documents and registration of a place of residence, provision or maintenance of housing, medical assistance, service, inspection of released persons, providing of additional guarantees of employment.

The law provides that subjects of social patronage in case of appeal to them, released persons are obliged to immediately start the implementation of such measures for social patronage. Financing of 
social patronage activities is carried out in accordance with the Budget Code of Ukraine. Additional financing is provided at the expense of funds, attracted on a voluntary basis by enterprises, institutions, organizations that are not in state ownership, associations of citizens and individuals.

Conclusions. It is obvious that social patronage will in future play a key role in providing of social services, namely: restoration of documents and registration of residence, provision or maintenance of housing, medical care, servicing, examination of released persons, provision of additional job security guarantees. As according to the Law, the subjects of social patronage are central and local executive authorities and local self-government bodies, enterprises, institutions and organizations, associations of citizens, as well as individuals who carry out social patronage. It is precisely for them today that they need to provide effective assistance in organizing above activities.

\section{References}

1. Palchenkova V. M. Transformatsiia hromadskoho kontroliu za vykonanniam pokaran: istoryko-pravovyi analiz [Transformation of public control over the execution of punishments: historical and legal analysis]: monohrafiia / V. M. Palchenkova. - Zaporizhzhia: Aktsent Invest-treid, 2013. - 524 s. (in Ukrainian).

2. Palchenkova V. M. Ideia ta praktyka tiuremnoho patronazhu v Rosiiskii imperii [The idea and practice of prison patronage in the Russian Empire] / V. M. Palchenkova // Derzhava ta rehiony. Naukovo-vyrobnychyi zhurnal. - 2013. - № 1. - (Seriia «Pravo»). - S. 18-23 (in Ukrainian).

3. Pro sotsialnu adaptatsiiu osib, yaki vidbuvaly pokarannia u vydi obmezhennia abo pozbavlennia voli na pevnyi strok [On the social adaptation of persons serving sentences in the form of restriction or deprivation of liberty for a certain period]: Zakon Ukrainy vid 10 lypnia 2003 r. [Law of Ukraine dated July 10, 2003] // Vidomosti Verkhovnoi Rady Ukrainy. 2004. - № 6. - St. 39 (in Ukrainian).

4. Pro sotsialnu adaptatsiiu osib, yaki vidbuvaiut, chy vidbuvaly pokarannia $u$ vydi obmezhennia abo pozbavlennia voli na pevnyi strok [On the social adaptation of persons serving or served sentences in the form of restriction or deprivation of liberty for a specified term]: Zakon Ukrainy vid 17 bereznia 2011 r. [Law of Ukraine dated March 17, 2011] // Vidomosti Verkhovnoi Rady Ukrainy. - 2011. - № 38. - St. 380 (in Ukrainian).

5. Yatsyshyn M. M. Pravovi osnovy sotsialnoho zakhystu osib, zvilnenykh z mists pozbavlennia voli [Legal bases of social protection of per- 
sons released from places of imprisonment] / M. M. Yatsyshyn // Naukovyi visnyk Uzhhorodskoho natsionalnoho universytetu. - 2009. - Seriia Pravo. Vypusk 12. - CH.2. - S. 511-516 (in Ukrainian).

Пальченкова В. М.

\section{ФУНКЦІОНУВАННЯ СОЦІАЛЬНОГО ПАТРОНАЖУ:} ТЕОРЕТИКО-ПРАВОВИЙ АСПЕКТ

Соціальний патронаж (термін походить від лат. "раtronиs», франц.. "patronage» - захисник, нагляд, заступництво, піклування) у буквальному розумінні передбачає будь-яке заступництво більш сильної у фізичному, моральному або юридичному розумінні особи стосовно слабшої. Заступництво може означати надання матеріальної, моральної в широкому розумінні сочіальної допомоги і підтримки.

У статті розглянуто різноманітні історичні види і форми патронажу. Залежно від суб 'єктів здійснення патронажу він міг бути державним, громадським або приватним, світським або иерковним; залежно від об'єктів - міг здійснюватися над рабами, вільновідпущеними або вільними людьми, стосуватися окремих категорій населення: дітей, жінок, колишніх повій, а також колишніх в'язнів (спеціальний тюремний патронаж).

Надано сучасне визначення патронажу, його суб' 'ктів $і$ заходів.

Законом визначено перелік послуг сочіального патронажу, до яких, крім соціальних, щуо визначені Законом Украӥни «Про сочіальні послуги», віднесено медичні, юридичні, освітні, реабілітаційні та інші послуги. Окреслено окремі заходи соціального патронажу, а саме: відновлення документів та реєстрація місия проживання, надання чи збереження житла, медична допомога, обслуговування, обстеження звільнених осіб, надання додаткових гарантій працевлаштування. Передбачено, щуо суб 'єкти соціального патронажу, в разі звернення до них звільнених осіб, зобов'язані невідкладно розпочати здійснення стосовно таких осіб заходи сочіального патронажу.

Ключові слова: сочіальний патронаж, сочүіальні послуги, форми, види, заходи.

\section{Пальченкова В. М. ФУНКЦИОНИРОВАНИЕ СОЦИАЛЬНОГО ПАТРОНАТА: ТЕОРЕТИКО-ПРАВОВОЙ АСПЕКТ}

Социальный патронат (термин происходит от лат. «раtroпиs», франи. "раtronage» - повелитель, покровитель, надзор, покровительство, попечительство) в буквальном смысле предполагает любое покровительство более сильной в физическом, моральном или юридическом понимании личности по отночению к слабой. Покровительство может означать предоставление материальной, моральной в широком смысле сочиальной помощи и поддержки.

В статье рассмотрены различные исторические виды и формы патроната. В зависимости от субъектов осуществления патроната он мог быть государственным, общественным или частным, светским или иерковным; в зависимости от объектов - мог осуществляться над рабами, вольноотпущенными или свободными людьми, касаться отдельных категорий 
населения: детей, женщин, бывщих проституток, а также бывщих заключенных (специальный тюремный патронат).

Представлено современное определение патроната, его субъектов и мероприятий.

Законом определен перечень услуг социального патроната, к которым, кроме соииальных, определенных Законом Украины "О соииальных услугах», отнесены медичинские, юридические, образовательные, реабилитационные и другие услуги. Определены отдельные мероприятия сочиального патроната, а именно: восстановление документов и регистрация места проживания, предоставление или сохранение жилья, медицинская помощь, обслуживание, обследование освобожденных лии, предоставление дополнительных гарантий трудоустройства. Предусмотрено, что субъекты соииального патроната, 6 случае обращения к ним освобожденных лии, обязаны безотлагательно начать осуществление в отношении таких лии мер социального патроната.

Ключевые слова: сочиальный патронат, сочиальные услуги, формы, виды, мерь. 